\title{
Reform Measures and Enlightenment of the Education Quality Assurance about Japanese Private Universities
}

\author{
Ting Zhang \\ School of Foreign Studies, Yangtze University, China \\ Email: 34515968@qq.com
}

Received 30 December 2015; accepted 26 January 2016; published 29 January 2016

Copyright (C) 2016 by author and Scientific Research Publishing Inc.

This work is licensed under the Creative Commons Attribution International License (CC BY).

http://creativecommons.org/licenses/by/4.0/

(c) (i) Open Access

\begin{abstract}
After the 90th, in order to strengthen the position of the global scientific and technological competition, Japan launched a series of higher education reform to protect the quality of education. The number of schools, the number of students accounted for more than $70 \%$ of the total number of private universities in Japan; there is no doubt that the key to the quality of the education is reform. After more than ten years of development, Japan has formed a set of relatively complete system of higher education quality assurance, which is based on the government as the leading, the University self-evaluation as the core, and the external third party evaluation as the core. This paper analyzes the characteristics of the education quality assurance of the Japanese Private University from the aspects of government, private universities, and the third party evaluation organizations. Through summarizing the characteristics and experiences of the education quality assurance of the private university in Japan, we can provide a useful reference for the quality assurance of private education in China.
\end{abstract}

\section{Keywords}

Japan, Private University, Quality Assurance, Reform Measures, Enlightenment

\section{Introduction}

Twenty-first century is a time dominated by the knowledge of science and technology. The competition between countries has gradually evolved into a contest between the comprehensive national strength, which is the core of scientific and technological strength. Especially in Japan, which is relatively small, the resources are relatively scarce, and the economy is in the downturn, it is expected to strengthen its position in the global scientific and technological competition by cultivating a large number of outstanding talents. This sense of urgency and mis- 
sion to Japan began to realize the importance of higher education quality. Therefore, to improve the quality of education for the purpose of higher education, reform gradually expands. On December 2012, Ministry of Education released the latest data, showing that among the total of 783 existing university in Japan, according to the establishment of the main divisions, the National Universities are 86 accounting for $11 \%$ of the total number of schools, public universities are 92 accounting for $12 \%$ of the total number of school, private universities reached 605 accounting $77 \%$ for the total number of schools. Among them, 621 universities have set up the graduate school, the National Graduate School and the public school graduate school respectively for $86,75,460$. The number of private universities has accounted for $77 \%$ of the total number of Japanese universities; the total number of students also accounted for 73\% of the total number of the country (Gamage, Suwanabroma, Ueyama, \& Sekikawa, 2008: pp. 181-198). Thus, the total number of private universities and the number of students in the school are far more than the sum of the number of public universities. However, private universities, teaching conditions and the public universities in contrast have a significant difference, private university teacher-student ratio as high as 1:30 and national university only 1:8, the private university students per capita campus area of 7.1 square meters and National University per capita 20.9 square meters, the overall teaching a backward in private university in the National University, but the tuition charge is about 4 times the National University (Shih, 2012). Therefore, it is the key to improving the education quality of private universities.

\section{Japanese Government through Legislative and Economic Means to Macro Control}

\subsection{Government Revised Education Law}

Through the reform of education system and the reform of the education system, the law should be amended in time to ensure the development of higher education in accordance with the actual conditions of the country. Therefore, the development of higher education in Japan has a close connection with the relevant policies of the government, which is a prominent feature of Japanese education. Japan has more than 80 kinds of higher education laws and regulations, these Regulations are not only the government's macro control of higher education policy, but also the legal basis for the protection of higher education in Japan (Tang \& Hussin, 2013: p. 11).

\subsubsection{The Two Revision of the University Setting Benchmark}

After the implementation of the University set benchmark in 1956, there have been no major changes until the University review in 1991, the first comprehensive revision of its. The main content of this revision has two points: first, to respect the academic freedom of the University, the government encourages the establishment of individual universities, therefore decided to relax the provisions of the unified, expanding the right to run universities. In particular, in the development of the teaching syllabus and the contents of the course of education policy to relax the university has more autonomy. The two is to prevent the university education quality has declined, therefore, it is suggested that the university has the obligation to carry out the self-appraisal and self-rating. In 1999, the University set up a benchmark for the second revision, the 91 years of the University from the "hard work obligations" to amend the terms of the "must be implemented" of the law, and the need to promptly publish the results, to ensure that the evaluation. The fairness and transparency, which means that all the universities have since then, must be regularly implemented self-evaluation to ensure the quality of school education. This is the first time from the point of view of law provisions of the university can be according to the school's educational philosophy, set up a special evaluation group to develop and the actual situation of the school, to adapt to the evaluation content and index, to improve the quality of school education for implementing school self-evaluation (Zhang \& Mccornac, 2013: p. 563). This as an opportunity, the Japanese higher education can be said to begin to enter in order to improve the quality as the core of the era, especially in the past because of legal protection of private university autonomy, private universities have more free education, only when private schools voluntarily apply for external evaluation of machine structure of the supervisory review and external agencies to intervention and evaluate the school. Now, after this legal amendment, private universities must improve the quality of education and scientific research, which is of great significance to the improvement of the overall education level of private universities.

\subsubsection{The Third Party Evaluation of University Outlook and Future Reform in Twenty-First Century}

The government had hoped to use the implementation of the University’s self-evaluation activities, and it is ex- 
pected that the university can set up the self-restraint mechanism, which can improve the quality of education in the absence of external institutions. However, in the process of self-evaluation system in the University, it is found that many private universities are due to the legal provisions of the passive implementation of College self-evaluation, which has lost the original rule of law to achieve the purpose of "to help the university to improve the level of education research" (Zhimin \& Wenting, 2014). And, because there is no supervision and inspection of the third parties, some universities have failed to take an objective and fair position, and the implementation of self-evaluation. Part of the school should not guarantee the impartiality of the self-rating, which will directly lead to the failure of the school self-assessment results and the loss of self-assessment activities of the implementation of the significance. Therefore, it is very important to introduce the third party evaluation at the time of the University's self-evaluation. To this end, the University considered. In the 98 year of the University of the University in twenty-first Century, and the future of the reform policy, the advisory report, on many occasions stressed the need for the introduction of the third party evaluation. "In order to make the society more clearly understood as a social institution of the University of Specific Activities, it is necessary to set up a specialized evaluation agency for the public and transparent university evaluation, to collect information on the evaluation of the University, to carry out the relevant survey". The report puts forward the effective implementation of multiple evaluations to guarantee the improvement of the quality of College education. The proposal soon be adopted by the Ministry of education minister, again revised the school education law is for the third party evaluation system in the form of legal confirmation, the provisions of Japan every university must accept the external mechanism of evaluation and supervision. The establishment of university evaluation and degree granting institution represents the increase of the main body of the external evaluation mechanism, and also means that Japan has begun to enter the era of higher education quality evaluation.

\subsection{The Government Support Funds to Guide}

In Japan, according to the constitution, private universities and national universities have more autonomy than those of the national universities. In particular, they are forbidden to have religious beliefs in the teaching of public universities. In this regard, the private university should not be subject to any direct control from the government, if the school does not violate the relevant laws, the government is no way to rely solely on legal means to penetrate into the private university operations management. But it is worth noting that the private universities in Japan in the development of higher education in the process of the important responsibilities, so the government should pay attention to improve the quality of postgraduate education, improve the overall level of private college teaching has become the key to the success of this task. As a means to monitor the normal operation of private universities, the government should not only establish a sound educational legal system, but also need to guide and support the appropriate financial support.

The basic development of private universities in the payment of the regular fee:

Because the economic foundation of private schools is weak, so the government is to protect the quality of education in private universities, according to the actual teaching conditions in private colleges and universities in accordance with the subsidy standards, a certain amount of financial aid to help them improve education environment. In recent years, because of the actual situation of higher education reform in Japan, the standard and calculation methods of the government financial subsidies will be slightly different, but the basic idea has not changed. At present, the actual use of funds from the division can be divided into facilities and equipment subsidies and regular expenses two. Facilities and equipment subsidies thoroughfare is self-evident, is used for graduate school and private school education on the improvement of the research equipment. The regular fee subsidy is also included in the two (Segerholm, 2012) (Figure 1). In this paper, the use and calculation method of the grant is studied.

\section{Self-Supervision of Private Universities}

In view of the diversity of university educational activities and social needs, the university itself needs more autonomy, and the education function of university education is not weakened. On the contrary, the university has the responsibility according to the society and the country's need to adapt to the high level talented person, also needs the university to own judgment the higher education development situation, and for this to carry on the related education reform positively. Government to increase the vitality of the University, to ensure the school personalized, modify the University set up the basic to relax the restrictions set by the University, as the cost to 


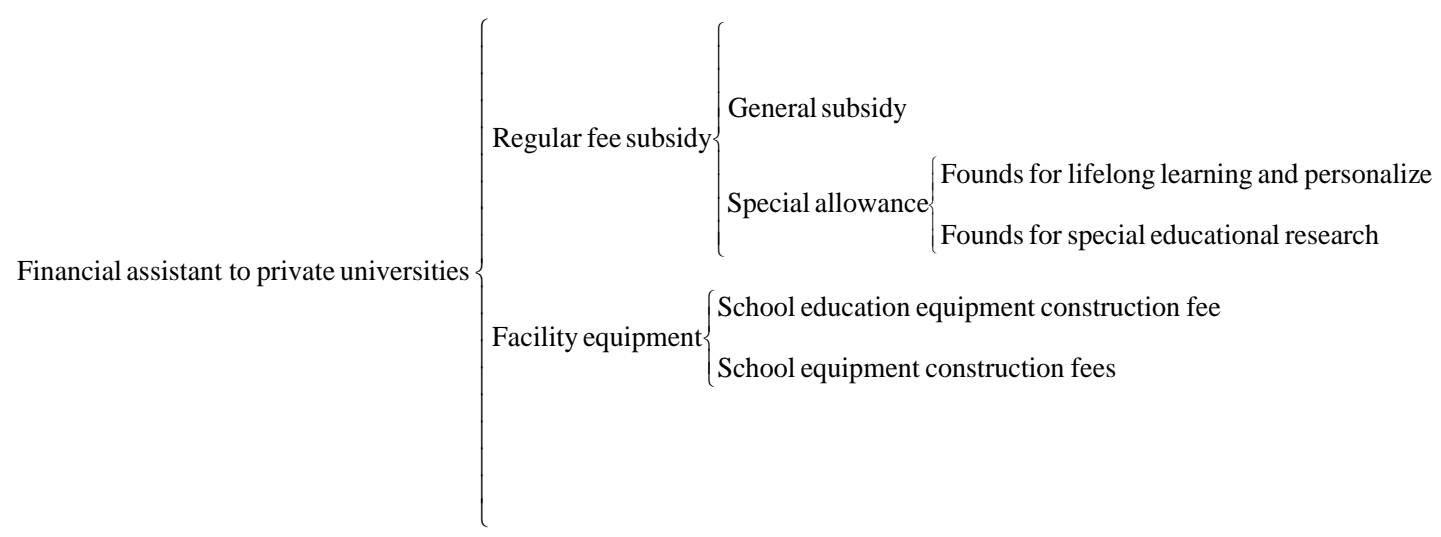

Figure 1. The classification of financial subsidy funds for private universities.

relax restrictions, the government asked Japan University on a regular basis the implementation of self-evaluation, according to the evaluation results showed that the inadequacies of the school and adjust, to protect schools to government requires minimum standard of education.

\subsection{Self-Rating System and Classification of Private Universities}

Self-evaluation of private universities, the first to set up a self-assessment of the implementation of the research group, is responsible for the development of the school's self-assessment content and evaluation index system, and then set up the school since the commission. Form has two forms respectively by school and all faculty jointly established by each department or the formation of a bicycle.

Including private universities, University self-evaluation form can be divided into five types: the overall evaluation object self-assessment, in the report submitted to the "university status and project name" to the public; to faculty, research department or Research Institute as the object of self-evaluation in the published report called "the University Faculty - Institute of self-checking self-assessment report"; or summary of research scholars personal experience and research results to "University researchers" published in the name of overview; according to the student survey results to evaluate the status quo and problem of "education" students see the name self-evaluation report is also common on the quality of teaching; finally, there is a type of self-evaluation is implemented in accordance with the specific subject self-evaluation, self-evaluation report published in the book "in University Education reform, the name, this is the University's most common five types of self-evaluation". Regardless of the type of self-evaluation is based on the actual situation of the school, and the implementation of school self-evaluation has become a private university to protect the quality of school education (Docherty, 2012: p. 674).

\subsection{Self-Rating and Process of Private University}

Each university in the implementation of self-evaluation can be based on the specific circumstances of the school, to decide the contents and evaluation criteria. But in "on the University's self-evaluation report" in the middle of the University self-evaluation key points in the system are described, requirements of College selfrating standards, evaluation content should reflect the various avoid monotony university spirit and personality characteristics of Japanese Private University Alliance Association according to the University and university evaluation review the benchmark Association recommendations, specifically for self-evaluation put forward some basic evaluation of private universities: project organization, including the Council of educational research organization, organization affairs authority and responsibility, private university student organization; teacher recruitment and evaluation of professional titles, including the number of teachers' teaching quantity, education and scientific research, academic achievements: participate in various education meetings; inter university cooperation mainly includes signing credit, mutual recognition between universities and foreign universities Exchange agreement, students studying abroad etc.; school education facilities and research equipment equipped with, including for education research in advanced facility, equipment and the equipment using rate, specialized equipment maintenance management etc.; school finance including, external funds, introduce situation, private 
finance financial ratios, or Ministry of education research funding the number and the amount of money (Shi \& Wang, 2011: p. 57). In fact, private university implementation of self-assessment evaluation contents are different, even if is the same evaluation content because of the differences in the ideas of running a school, self-rating standards focus will not the same.

\section{Establishment the Third Party Evaluation Mechanism for the Introduction of External Evaluation System}

After 2004, Japan began to enter the era of the perfection of the external evaluation system, the quality of private university education is no longer only rely on the school from the evaluation, the intervention of the third party evaluation agency has become an important part of the quality of private universities. External evaluation can be divided into two, A is authorized by the Ministry of education minister formal third-party evaluation institutions, and another is by social media a university rankings.

\subsection{The Third Party Organizations of the Private Universities as the Evaluation Object}

At present, in the Japanese professional external evaluation mechanism about ten, will be the main mechanism according to the established division of the main can be divided into three categories. The first is college group, consisting of rating agencies, the main representative body for benchmark University Association, Japan higher education evaluation institutions; the second is type of quasi government set up by the government of evaluation mechanism, main representative for university evaluation, degree granting institutions; the third is by professional groups formed spontaneously designed for a particular area of assessment institutions, is the main representative Japanese technology education certification bodies. The three types of assessment agencies responsibities, although university group composition evaluation mechanism can be to evaluate any type of University. However, as a result of the establishment of the university evaluation and degree granting institution, the main task of the National University is to be borne by the institution. Thus, some of the spontaneous formation of the university evaluation body can only be responsible for the evaluation of private universities.

\subsection{Social Media Evaluation of University Rankings}

In recent years, the private universities in Japan not only to receive regular professional third-party evaluation institutions of supervisory review, also appeared in the non-official, non-specialized agencies by social media is newspapers and magazines or another external evaluation by commercial companies according to the needs of society custom standard. With the introduction of university competition mechanism and the concern of students and parents, the external evaluation of social media is becoming more and more attention. In the future, it will gradually become a new trend of external evaluation of Nihon University (Douglas, 2014: p. 301). Universities need to use the media to carry out self-propaganda, especially the private universities to tuition fees as the main source of income of the school. Therefore, to the society the majority of students and parents show the characteristics of school running, the media students in broad strokes is a necessary means to the school, candidates need to know the university entrance exam difficulty, teaching quality, fees and other detailed information. Enterprises need.

The latest scientific research results, outstanding graduates and other information, media evaluation is also due to the above reasons and quietly rising. Universities want to get a higher ranking in the media, we should play the school characteristics, and continuously improve the quality of running schools, and increase investment in education and scientific research. It can be said, through the university rankings, the University in the competition with other colleges and universities in the same time, also promoted the private university to improve the quality of the school, so the media ranking is an important part of the quality assurance system.

Because Asahi news agency launched the university ranking of the basic situation of all universities in Japan are introduced, index evaluation is more objective, so that it has become Japan most of university rankings, accredited degree is very high. It can be said that the external evaluation of social media properties has become an important form of the mass media and non-governmental organizations in Japan (Power, 2015). To the community, evaluation of the project close to life, the evaluation method of intuitive, even if it is not relevant professional knowledge of people can also through the university ranking the overall level of the domestic universities have more intuitive and clear understanding. For the government education department, the university ranking 
from the other side reflects the quality of education in the domestic university, can be used as a means to understand the situation of the University, as a practical basis for the macro regulation and control. In the University, it can be found that the deficiencies of the university can be found directly through the horizontal comparison of other universities.

\section{The Enlightenment of the Reform of the Quality of Education in the Private Universities in Japan}

According to China's Ministry of education in March 2013 the latest data show that at present, there are 698 private schools, the number of students in the school of 5,050,687 people, including 3,118,236 college students accounted for 1,932,451 of the college students. The scale of private education is expanding, but whether it is public or private enterprise, the recognition of the graduates of private colleges and universities is low, the main reason is that the quality of private school education is still a big gap in the quality of education in public universities. Therefore, the quality of education is the lifeblood of private schools. To improve the quality of education for private schools, not only the inner requirements of the mission of the school education, but also the private schools want to survive, to compete in the education market for the basic requirements of students.

\subsection{Factors Affecting the Quality of Private Education in China}

\subsubsection{Policy Revision Lag, the Legal System Is Not Perfect}

So far, involving private higher education laws and regulations are mainly in 1993 the private colleges and universities set up Interim Provisions, the 1997 the schools run by social forces Ordinance, 2002 the private education promotion law, in 2004 the "Private Education Promotion Law Implementation Regulations", in 2007 the "private higher school management several provisions" (Sheng, 2013). The promulgation of these laws can be said to be a transition process from the recognition of the legal status of private colleges and universities, to encourage the construction of private colleges, and to provide legal protection for the long-term development of private education. From a long-term perspective, the need for long-term development of private education is still not enough legal support. For example, regulate local documents and the education law of the basic spirit is not completely consistent, a direct result of the law operability is not strong and difficult to implement; supporting policies such as preferential tax policies for private colleges and universities delays in the introduction; timely for private colleges and universities indicates the direction of education reform in the policy lag seriously; private education laws and administrative rules and regulations still exist many disharmonies. These are highlighting the legal system of private education in China is not perfect.

\subsubsection{The Autonomy of Running a School Is Not Fully Guaranteed}

Although private schools and public schools have equal legal status, the autonomy of private schools has not been truly implemented. First of all, we can't set up the professional and curriculum, which makes the private schools can't play their own characteristics, resulting in a growing homogenization of the trend. Secondly, enrollment plan is strictly controlled, so that the private schools can't follow the efficiency of the principle of autonomy for resource optimization allocation, and can't be expected to respond to market information and actively take measures to respond to the expected response. Finally, the strict examination and approval system, although the effective control of the phenomenon of private schools, but in the absence of government investment, the students lack of tuition fees charged under strict control, leading to the shortage of funds in private colleges and universities, lack of funds for improving the education environment of the school.

\subsubsection{Lack of Government Funding, School Funding Shortage}

Capital is not only related to the normal running of private colleges and universities, but also one of the key factors to improve the quality of private education. At present, the shortage of funds in many private colleges and universities in China is mainly due to the collection of tuition fees. However, the characteristics of private colleges and universities can't be played and the quality of school education can't be recognized by the majority of the community. The private colleges and universities in China are relatively simple, and the government has a lower proportion of funds in private colleges. Moreover, the source of the funds from the private school is also one of the reasons which lead to the shortage of funds. 


\subsubsection{Private Colleges and Universities Quality Evaluation Standard Single}

The relevant departments in the implementation of the private higher education quality assessment are often applied to the index system of public schools and private schools in the concept of education, the quality of students, school conditions, management mechanism and the public school differs very far, which makes with single evaluation standard of quality assessment of the quality of Education of private schools is unrealistic, but also a serious impact on the diversity of development of civilian run colleges and universities. The scientific quality assessment has a vital impact on the local people in the local government, the formation of the characteristics and the future development direction. Therefore, the government's single quality assessment is bound to affect the long-term development of private colleges and universities.

\subsection{Measures for the Implementation of Education Quality Assurance in Private Colleges and Universities in China}

\subsubsection{Improve the Legal System, Improve the Implementation Details}

The reason why the private universities in Japan have been able to develop into today's scale, which has a great relationship with the government's attention to private universities. Legal protection for the development of private university laid the legal protection, and for private universities to create a relaxed environment for the development, Japanese Private University and the national public universities by the legal protection enjoyed full autonomy in running schools, the situation in private schools is not illegal government only through fiscal means to guide the development of private universities. At present, China has fully affirmed the legal status of private colleges and universities. In the next to improve the quality of private education, the government should attach great importance to the development of private education according to the actual situation of the relevant laws and regulations. Each local government and the education department as soon as possible to introduction supporting measures, and earnestly implement the relevant laws and regulations, in a high degree of legal system of private colleges and universities to go further.

\subsubsection{Government to Increase Financial Investment, Colleges and Universities to Broaden the Funding Channels}

Japan's financial aid to private universities is also an important reason for the success of private universities. The government's most direct financial aid to private universities is often the cost of subsidies, including support for school teaching facilities, insurance funds, and the development of school characteristics. Indirect financial aid is the distribution of special competition funds, giving private universities and public universities in the same competition platform, encourage private universities to participate in scientific research and competition, which promotes the school's scientific research activity to improve the level of school education. In addition, the transfer of corporate and private donations, project results are one of the sources of funding for private universities. In contrast, China's private colleges and universities rely on tuition fees to maintain the school operations, it is difficult to guarantee the quality of its education. Therefore, the government to increase the financial allocation of private universities, the introduction of school tax or loan terms of preferential policies, to emulate Japan will be combined with financial subsidies, to stimulate the school to implement the quality of self-education. Moreover, the government should make a positive contribution to the social contribution, the enterprise financial support to create a good social atmosphere, private colleges and universities should not only rely on government funding, and actively develop personalized education for the community wide support to make due efforts.

\subsubsection{Pay Attention to the University's Self-Evaluation, the Establishment of the External Evaluation Mechanism}

The higher education assessment in China has been carried out as an administrative work, although the educational administrative power and the executive power are guaranteed, but the evaluation of the activities of the single and the evaluation method is unified, it is difficult to guarantee the characteristics of the private school development and quality evaluation of the scientific nature of the two (Liu, Li, \& Yang, 2012). But the private colleges and universities education quality guarantee can't depend on the external force, actually the private colleges and universities, their own shortcomings is more clear than the external evaluation mechanism. Therefore, relevant educational administrative departments to strengthen supervision of the quality of colleges and universities, similar to Japan for private colleges and universities self-evaluation implementation outline, clear 
self-evaluation content and evaluation criteria of rules determined by the universities themselves, so as to periodically conduct self-check assessment to promote private colleges and universities, but also conducive to private schools play school characteristics. Additionally draw the successful experience of Japanese civil society third-party evaluation institutions to establish, gradually establish a authoritative social intermediary organizations, and give full play to the role of intermediary organizations in the private higher education quality evaluation, from the past rely solely on government administrative means to safeguard private education of quality of education, to school self-evaluation based on agency implementation of the supervision and direction of the transition, the government through legal and economic means of macroeconomic regulation and control.

\section{Conclusion}

In this study, we choose private universities as the research object, and study the function and function of different subjects in the protection of the quality of education in private universities. As the "university setting standards" is not conducive to the development of private universities, the Japanese government in the 90 years after the Japanese government to amend the "University set standards" to make it an outline of. Set the benchmark of the outline of the school to give the full power, but because of the concern about the quality of school teaching and therefore decline, therefore, the school must be regularly implemented school self-assessment. Since the implementation of the seven years of assessment activities, some schools do not stand in the objective position of the implementation of self-evaluation of the drawbacks of the beginning, the government began to introduce the third party evaluation system. Since then, Japan has formed a set of relatively perfect quality assurance system, which is the same as the government, the school, the third party evaluation mechanism. The government can provide funds for private universities to improve the educational conditions of the University, which is expected to improve the overall education level of the private universities, and provide professional talents for the national economic development. The private university itself is the guarantee of the quality of education will be implemented regularly self-evaluation, and the evaluation results are summarized into a report submitted to the third party evaluation institutions to accept external review. The spontaneous formation of the society is evaluated according to the evaluation idea and standard of the organization. Through the research found that Japanese private university education quality assurance very distinct characteristics, government to establish and improve the policies and regulations as specified in the direction of the education reform, and the multi subject evaluation coexistence and complementary security in various ways on the quality of private higher education implementation of security, this approach both can effectively protect the private university education quality at the same time, but also to take into account the private school characteristics of the school. However, in order to protect the private university education quality process, there are many problems, such as the intention of the government's macroeconomic regulation and control, to enhance university self-rating results because each school custom content and standard of evaluation result to the horizontal comparison between schools, third party evaluation organization and the United States recognized the organization than a functional authority is too small and the role of external evaluation is restricted. In short, the private universities take on the task of educating the masses, and play an important role in improving the quality of the people. Therefore, whether it is to promote social and economic development or in order to ensure the competitiveness of the country, the quality of education in private colleges and universities is the important issue of higher education reform in Japan.

\section{References}

Docherty, T. (2012). Research by Numbers. Index on Censorship, 41, 674. http://dx.doi.org/10.1177/0306422012456132

Gamage, D. T., Suwanabroma, J., Ueyama, T., Hada, S., \& Sekikawa, E. (2008). The Impact of Quality Assurance Measures on Student Services at the Japanese and Thai Private Universities. Quality Assurance in Education, 16, 181-198.

Liu, K., Li, Y., \& Yang, X. (2012). The Reform and Enlightenment of Australian Higher Education Quality Assurance in New Period. Shanghai Journal of Educational Evaluation.

Power, C. (2015). Higher Education: The Engine of Development. In The Power of Education. Singapore: Springer. http://dx.doi.org/10.1007/978-981-287-221-0_10

Segerholm, C. (2012). Global Evaluation and Quality Assurance Policy Meet Local Education Context. In Enlightenment, Creativity and Education. Sense Publishers. http://dx.doi.org/10.1007/978-94-6209-052-1_8

Sheng, Z. F. (2013). The Reform of Higher Education Quality Assurance in Netherlands and Its Enlightenments. Evaluation 


\section{\& Management.}

Shi, J., Li, G., \& Wang, P. (2011). Anthropogenic Influences on the Tidal Prism and Water Exchanges in Jiaozhou Bay, Qingdao, China. Journal of Coastal Research, 27, 57-72. http://dx.doi.org/10.2112/JCOASTRES-D-09-00011.1

Shih, C. H. (2012). The Effects of Governmental Subsidy on the Quality of Education in Taiwan's Private Universities and Colleges. In Network and Parallel Computing. Springer Berlin Heidelberg. http://dx.doi.org/10.1007/978-3-642-35606-3_43

Tang, S. F., \& Hussin, S. (2013). Advancing Sustainability in Private Higher Education through Quality Assurance: A Study of Two Malaysian Private Universities. Asian Social Science, 9. http://dx.doi.org/10.5539/ass.v9n11P270

Zhang, R., \& Mccornac, D. C. (2013). The Need for Private Universities in Japan to Be Agents of Change. International Journal of Educational Management, 27, 562-577. http://dx.doi.org/10.1108/ijem-08-2012-0091

Zhimin, T., \& Wenting, X. (2014). The Philosophy Teaching Assessment System and Its Enlightenments of British Universities. Cross - Cultural Communication, 10, 46-52. 